\title{
ELASTISITAS HARGA TELUR TERHADAP MINAT PETERNAK AYAM PETELUR DALAM MENGEMBANGKAN USAHA PETERNAKANNYA (Studi Kasus Di Desa Sukolilo Kecamatan Wajak Kabupaten Malang)
}

Anna Lidiyawati

Program Studi Peternakan Universitas Nahdlatul Ulama Blitar

\begin{abstract}
Abstrac
This research was conducted to layer farmers in Sukolilo village, Wajak in Malang distric .The data collection was conducted during Desember 2017 - January 2018 that focus on elasticity of egg price to farmer interest of develop their farming. Research method used is a method of survey sample with determination of the sampling method purposively namely layer chicken farmers who had 300-3000 chickens. The number of the overall sample can be reserach used is egg price, number of the population, feed price, pullet price, afkhir of layer price. Data analysis conducted includes data qualitative and analysis to calculate the elasticity of egg price by used Cobb-Douglas regression analysis. Data prosesscing from the result of this research condusted using the the SPSS version 16,0. The result show that afkhir of layer price have significant to affect elastic of egg price. The research concluded that 1) afkhir of layer price is a factor have significant affect to farmer interest of develop their farming and elastic to egg price 2) number of population, feed price and pullet price are the factors that are not elastic to egg price.
\end{abstract}

Keywods : elasticity of egg price, number of population, feed price, pullet price, afkhir of layer price

\section{PENDAHULUAN}

Fluktuasi harga telur yang tidak stabil menjadi pertimbangan mendasar dari peternak kecil dalam mengembangkan usahanya. Selama periode Februari - Juli 2018 harga telur mengalami kemerosotan bahkan sempat dibawah harga pokok produksi karena over produksi khususnya di daerah blitar (kementan, 2017). Melalui Kepmentan no.3035/2017 pemerintah berusaha menstabilkan harga telur dengan jalan penurunan populasi yakni dengan afkhir dini umur 70 minggu untuk peternak dengan populasi diatas 100 ribu. Langkah ini tenyata cukup memberikan hasil yang memuaskan sedikit demi sedikit harga telur mulai merangkak naik. Supply dan demand mulai seimbang.

Di sisi lain konsumsi protein hewani masih rendah sehingga pengembangan usaha ternak layer (ayam petelur) di Indonesia masih memiliki prospek yang bagus. Menurut Badan Pusat statistik rata-rata konsumsi telur per kapita selama seminggu pada tahun 2015 adalah 1,940 kg. Dengan asumsi berat telur per telur adalah 0,05 kg. Maka kebutuhan telur per minggu adalah sekitar 38 butir. Meningkatnya jumlah konsumsi telur dibarengi dengan meningkatnya jumlah produksi telur .Sesuai SNI konsumsi 
protein perhari per kapita ditetapkan $55 \mathrm{~g}$ yang terdiri dari $80 \%$ protein nabati dan $20 \%$ protein hewani (www.litbang.deptan.co.id). Meningkatnya konsumsi protein hewani akan berdampak pada meningkatnya kualitas SDM.

Usaha peternakan ayam petelur yang berkembang didesa umumnya merupakan usaha sampingan. Fenomena ini bisa dilihat dari pergeseran aktivitas petani dari hanya bercocok tanam menjadi memelihara ternak . Disamping telur sebagai produk utama yang dihasilkan penjualan daging dan feses juga merupakan penghasilan tambahan dari usaha peternakan ayam petelur. Sehingga usaha peternakan ayam petelur dinilai sangat memiliki peluang besar dalam meningkatkan pendapatan petani selain pemeliharaan yang tidak menyita waktu. Oleh karena itu banyak petani ternak yang ingin mengembangkan usahanya.

Oleh karena itu perhitungan dan analisa ekonomi yang tepat diperlukan untuk mengetahui efisiensi usaha guna memperoleh hasil yang maksimal. Aspek yang perlu dianalisis untuk mengetahui minat peternak dalam mengembangkan usahanya adalah harga telur yang berfluktuasi.

Penelitian ini bertujuan untuk mendeskripsikan faktor-faktor yang mempengaruhi harga telur dan menganalisis elastisitas harga telur terhadap minat konsumen dalam mengembangkan usahanya.

\section{METODOLOGI PENELITIAN}

\section{Analisa data}

Analisa data digunakan untuk mengetahui pengaruh variabel dependen yang meliputi harga telur terhadap beberapa variabel independen yaitu minat peternak ayam petelur dalam mengembangkan usahanya adalah uji regresi model Cobb-Douglas ( Soekartawi,2003), analisa data menggunakan program Statistical Package for the Social Science (SPSS).

Analisa faktor-faktor yang mempengaruhi minat peternak ayam petelur dalam mengembangkan usahanya diolah secara statistik dengan persamaan regresi model Cobb-Douglas.

Persamaannya adalah :

$$
\mathrm{Y}=\mathrm{a} \mathrm{X}_{1}^{\mathrm{b} 1} \mathrm{X}_{2}^{\mathrm{b} 2} \mathrm{X}_{3}^{\mathrm{b} 3} \mathrm{X}_{4}^{\mathrm{b} 4} \mathrm{e}^{\mathrm{u}}
$$

Keterangan :

Y : Harga Telur (rupiah/kg)

a : Konstanta

$\mathrm{b}:$ Koefisien regresi

e : Bilangan natural $(2,718281828)$

$\mathrm{u}$ : Disturbance

X1 : Jumlah Ternak (ekor)

$\mathrm{X} 2$ : Harga Pakan (rupiah/kg)

X3 : Harga Pullet (rupiah/ekor) 
X4: Harga Ayam Petelur Afkhir (rupiah/ekor)

Untuk mempermudah maka persamaan diatas dapat diturunkan dalam bentuk regresi linier sebagai berikut :

$\ln \mathrm{Y}=\ln \mathrm{a}+\mathrm{b}_{1} \ln \mathrm{X}_{1}+\mathrm{b}_{2} \ln \mathrm{X}_{2}+\mathrm{b}_{3} \ln \mathrm{X}_{3}+\mathrm{b}_{4} \ln \mathrm{X}_{4}+\mathrm{u} \ln \mathrm{e}$

Analisa data didahului dengan uji normalitas dan uji asumsi klasik. Uji normalitas bertujuan untuk menguji apakah dalam model regresi, variabel penggangu memiliki distribusi normal. Uji normalitas data dilakukan dengan uji Kolmogorov-Smirnov. Suatu data dikatakan normal apabila nilai signifikansi yang uji t. Uji F digunakan untuk menguji pengaruh variabel independen terhadap variabel dependen secara serempak. Uji t digunakan untuk menguji pengaruh variabel independen terhadap variabel dependen secara parsial. Ekowati et al (2014) menyatakan bahwa dalam bentuk fungsi tipe CobbDouglas, maka koefisien b telah mencerminkan elastisitas. Jika elastisitas $b=1$ maka termasuk elastis uniter. Jika $b>1$ maka dapat dikatakan elastis, jika $b<1$ maka dikatakan inelastis.

\section{Elastisitas Harga}

Elasitas adalah derajat kepekaan kuantitas yang diminta atau yang ditawarkan terhadap salah satu faktor yang mempengaruhi. Elastisitas menjelaskan respon perubahan kuantitas yang diminta jika harga, pendapatan dan faktor-faktor lain berubah. Konsep elastisitas harga menunjukkan bahwa perubahan harga akan menyebabkan perubahan faktor yang diminta. Secara khusus elastisitas harga terhadap minat didefinisikan sebagai persentase perubahan minat sebagai respon atas perubahan harga. Bentuk matematisnya adalah :

$$
\mathrm{E}_{\mathrm{Q} . \mathrm{p}}=\frac{\text { Perubahan } Q}{\text { Perubahab } P}
$$

Elastisitas ini menunjukkan bagaimana perubahan Q dalam nilai persentase merespon perubahan P. Elastisitas harga $\mathrm{E}_{\mathrm{Q} . p}$ ini dikatakan elastis jika nilai absolutnya lebih dari satu dan dikatakan inelastis jika kurang dari satu.

\section{Tempat dan Waktu Penelitian}

Penelitian ini dilakukan di Desa sukolilo Kecamatan Wajak Kabupaten Malang pada bulan Desember 2017 - Januari 2018. Lokasi pengambilan data dilakukan pada sejumlah peternak ayam layer. Pemilihan tempat ini dilakukan karena desa Sukolilo merupakan sentra ayam layer yang sedang berkembang.

\section{Pengumpulan Sampel Data}

Jumlah sampel sebanyak 40 peternak layer yang dipilih berdasarkan kepemilikan ternak. sampel peternak yang diambil adalah peternak yang mempunyai jumlah ternak 300-3000 ekor. 


\section{HASIL DAN PEMBAHASAN}

\section{Data hasil Penelitian}

\begin{tabular}{|c|c|c|}
\hline $\begin{array}{l}\text { Variabel } \\
\text { Dependen }\end{array}$ & $\begin{array}{l}\text { Variabel } \\
\text { Independent }\end{array}$ & Beta \\
\hline \multirow{5}{*}{$\begin{array}{c}\text { Harga } \\
\text { Telur (Y) }\end{array}$} & $\begin{array}{l}\text { Konstanta } \\
\text { (Constant) }\end{array}$ & \\
\hline & Jumlah ternak $\left(\mathrm{X}_{1}\right)$ & 0,333 \\
\hline & Harga Pakan $\left(\mathrm{X}_{2}\right)$ & $-0,077 * *$ \\
\hline & Harga Pullet $\left(\mathrm{X}_{3}\right)$ & $0,22 * *$ \\
\hline & $\begin{array}{l}\text { Harga Ayam } \\
\text { Afkhir }\left(\mathrm{X}_{4}\right)\end{array}$ & $-0,038^{* * *}$ \\
\hline & Nilai $\mathrm{R}$ & 0,325 \\
\hline & R Square $\left(R^{2)}\right.$ & 0,106 \\
\hline & Adjusted R Square & 0,03 \\
\hline & Nilai F & 1,033 \\
\hline
\end{tabular}

Keterangan :** $: \mathrm{P}<0,01 ; *: \mathrm{P}<0,05$

Sumber (Data Primer (diolah), 2018)

Persamaan regresi :

$$
\begin{aligned}
& \mathrm{Y}=17077,5 \mathrm{X}_{1}{ }^{0,333} \mathrm{X}_{2}{ }^{-0,077} \mathrm{X}_{3}{ }^{0,22} \mathrm{X}_{4}{ }^{-0,038} \\
& \mathrm{Y}=\text { harga telur }(\mathrm{Rp} / \mathrm{kg}) \\
& \mathrm{X}_{1}=\text { jumlah ternak }(\mathrm{ekor}) \\
& \mathrm{X}_{2}=\text { harga pakan }(\mathrm{Rp} / \mathrm{kg}) \\
& \mathrm{X}_{3}=\text { harga pullet }(\mathrm{Rp} / \mathrm{ekor}) \\
& \mathrm{X}_{4}=\text { harga ayam afkhir (Rp/kg bobot hidup) }
\end{aligned}
$$

\section{Faktor-Faktor yang Mempengaruhi Peternak dalam Mengembangkan Usahanya}

1. Jumlah Ternak

Hasil angka pengolahan data menunjukkan bahwa terdapat hubungan yang positif dengan minat peternak dalam mengembangkan usahanya. Variabel jumlah ternak mencetak nilai koefisien regresi sebesar 0,333 artinya jika jumlah ternak meningkat sebesar $1 \%$ sedangkan faktor lain dianggap konstan maka minat peternak dalam mengembangkan usahanya juga meningkat 0,333\%. Jumlah ternak merupakan variabel yang sangat mempengaruhi dalam mengembangkan usaha peternakan. Semakin banyak jumlah yang dipelihara maka semakin besar pula pendapatan peternak. Jumlah kepemilikan ternak akan menentukan penerimaan yang akan diperoleh, karena semakin banyak populasi yang dimiliki maka semakin meningkat pula pendapatan yang diperoleh (Siregar, 2009) .

\section{Harga Pakan}

Hasil analisis regresi memperlihatkan bahwa variabel harga pakan memberikan pengaruh yang sangat signifikan terhadap minat peternak dalam mengembangkan 
usahanya. Besarnya nilai angka koefisien regresi variabel harga pakan sebesar 0,077 yang dapat diartikan bahwa jika biaya pakan meningkat sebesar $1 \%$ sedangkan faktor lain dianggap tetap maka harga telur akan turun sebesar 0,077\%. Variabel harga pakan merupakan parameter bagi peternak dalam mengembangkan usahanya. Mengingat $60 \%$ dari total biaya produksi adalah biaya pakan. Hal ini sesuai dengan Sumartini dan Yunus (2009) yang menyatakan bahwa biaya pakan mencapai 58,13-66,2\% dari seluruh biaya operasional.

\section{Harga Pullet Ayam Petelur}

Pullet adalah istilah yang sering digunakan untuk ayam ras petelur yang berada pada masa grower (pra-petelur) yang biasanya berumur 10-16 minggu. Hasil pengolahan data mentah yang dianalisis menggunakan pendekatan regresi didapatkan hasil bahwa harga pullet berpengaruh sangat signifikan terhadap minat peternak dalam mengembangkan usahanya. Hal ini berhubungan dengan nilai koefisien regresi mencetak angka 0,022 artinya jika harga telur naik $1 \%$ sedangkan faktor lain dianggap konstan maka harga pullet naik $0,022 \%$.

\section{Harga Afkhir Ayam Petelur}

Berdasarkan pengolahan data dengan menggunakan analisis regresi dapat dilhat bahwa variabel harga pullet memberikan pengaruh yang sangat signifikan terhadap minat peternak dalam mengembangkan usahanya. Hal ini berhubungan dengan nilai koefisien regresi mencetak angka -0,038 artinya jika harga telur naik $1 \%$ sedangkan faktor lain dianggap konstan maka harga ayam afkhir menurun $0,038 \%$.

Untuk mengurangi biaya produksi yang meningkat sedangkan harga telur yang merosot peternak seringkali melakukan pengafkhiran lebih awal (Nuryati, 2012). Hal ini terpaksa dilakukan agar peternak tidak terus mengalami kerugian.

\section{Analisis Elastisitas Harga Telur Terhadap Minat Peternak Dalam Mengembangkan Usahanya}

1. Elastisitas Jumlah Ternak

Model fungsi minat peternak yang digunakan menunjukkan gambaran bahwa angka koefisien regresi variabel jumlah ternak mencetak nilai Koefisien regresi mencetak angka 0,333 artinya jika harga telur naik $1 \%$ sedangkan faktor lain dianggap konstan maka jumlah ternak tidak ikut naik $0,333 \%$ (nilai sig $0,051>0,05$ )

Faktor jumlah ternak bersifat tidak elastis terhadap harga telur. Meningkatnya jumlah ternak akan meningkatkan jumlah telur yang dihasilkan akibatnya harga telur turun. Turunnya harga telur merupakan salah satu pertimbangan peternak dalam mengembangkan usahanya. Kondisi peternakan kita pada saat ini adalah over supply dimana produksi daging maupun telur lebih banyak dari permintaan akibatnya harga turun. Sehingga salah satu kebijakan dari pemerintah melalui Keputusan Menteri Pertanian No. 3035 Tahun 21017 tentang pengaturan supply dan demand melalui penyesuaian jumlah final stock. Salah satunya untuk peternak layer yang memiliki ayam petelur dengan kapasitas produksi diatas 100 ribu ekor diminta untuk afkhir dini yakni 
70 minggu. Dengan berkurangnya jumlah populasi ternak diharapkan terjadi keseimbangan antara supply dan demand sehingga harga telur bisa stabil .

\section{Elastisitas Harga Pakan}

Faktor biaya pakan bersifat tidak elastis, hal ini dapat dijelaskan bahwa faktor harga pakan belum memberikan kontribusi besar terhadap kenaikan harga telur. Hasil perhitungan biaya pakan pada tabel menunjukkan angka Rp.4613,-/kg. Angka ini menggambarkan kenyataan bahwa harga pakan masih dianggap belum mempengaruhi kenaikan biaya produksi. Perusahaan pakan ternak mempunyai kalkulasi perhitungan secara menyeluruh untuk menentukan kenaikan harga pakan sehingga seringkali peternak diminta pengertiannya untuk tetap beternak dalam kondisi yang sulit. Dalam hal ini kebijakan pemerintahlah yang paling berkompeten untuk menyelesaikan masalah stabilitas harga. Sehingga kenaikan harga pakan tidak berimbas pada turunnya harga telur. Perlindungan terhadap peternak ini tentu saja sangat penting untuk melindungi peternak dari ancaman penutupan usahanya.

\section{Elastisitas Harga Pullet}

Hasil pengolahan data mentah yang dianalisis menggunakan pendekatan regresi didapatkan variabel harga pullet mencetak nilai koefisien regresi 0,022 artinya jika harga telur naik $1 \%$ sedangkan faktor lain dianggap konstan maka harga pullet naik $0,022 \%$.

Variabel harga pullet bersifat tidak elastis dikarenakan koefisisen regresi belum memberikan kontribusi terhadap harga telur. Dari data diketahui bahwa harga pullet berkisar Rp. 55.000. Kenyataan ini menjelaskan bahwa harga pullet relatif masih terjangkau. Dalam usaha peternakan ayam petelur harga pullet merupakan salah satu faktor yang menentukan biaya produksi. Pemeliharaan pullet untuk peremajaan ternak ayam petelur disinyalir lebih menguntungkan dibanding pemeliharaan mulai DOC.

\section{Elastisitas Harga Afkhir Ayam Petelur}

Hasil pengolahan data dengan menggunakan analisis regresi menunjukkan nilai koefisien regresi mencetak angka $-0,038$ artinya jika harga telur naik $1 \%$ sedangkan faktor lain dianggap konstan maka harga ayam afkhir menurun $0,038 \%$. Faktor harga ayam afkhir bersifat elastis terhadap kenaikan harga telur. Kenaikan harga telur disebabkan jumlah populasi ayam petelur berkurang sehingga produksi menurun. Angka elastisitas harga selalu bernilai negatif karena sifat variabel harga dan jumlah barang yang diminta bersifat terbalik (Firdaus, 2008). Harga ayam afkhir yang tinggi merangsang minat peternak dalam mengembangkan usahanya karena pendapatan dari ayam afkhir merupakan pendapatan tambahan disamping telur sebagai pendapatan utama 


\section{KESIMPULAN DAN SARAN}

\section{Kesimpulan}

1. Variabel jumlah ternak dan harga pakan merupakan faktor-faktor yang signifikan dalam mempengaruhi minat peternak untuk mengembangkan usahanya sedangkan harga pullet dan harga ayam afkhir merupakan faktorfaktor yang sangat signifikan dalam mempengaruhi minat peternak untuk mengembangkan usahanya.

2. Harga ayam afkhir merupakan faktor yang mempengaruhi minat peternak dalam mengembangkan usahanya dan bersifat elastis terhadap kenaikan harga telur, sedangkan jumlah ternak, harga pakan dan harga pullet merupakan faktor yang mempengaruhi minat peternak dalam mengembangkan usahanya dan bersifat tidak elastis terhadap kenaikan harga telur

\section{Saran}

1. Mengadakan penelitian lebih lanjut tentang faktor-faktor yang mempengaruhi keberlanjutan usaha peternakan

2. Peternak lebih teliti dalam mencermati fluktuasi harga telur sehingga mampu menentukan waktu yang tepat untuk mengembangkan usahanya dengan memperhatikan faktor-faktor jumlah ternak, kenaikan harga pakan, harga pullet dan harga ayam afkhir sehingga bisa meminimalkan resiko kerugian dan memaksimalkan pendapatan.

3. Adanya kerjasama antara berbagai pihak antara lain peneliti, peternak dan pemerintah dalam mendukung berkembangnya usaha peternakan

\section{DAFTAR PUSTAKA}

Amrullah, I. 2003. Nutrisi Ayam Petelur. Satu Gunung Budi. Bogor

Febrianto N dan Putritamara, J.A. 2017. Proyeksi Elastisitas Permintaan Telur Ayam Ras di Malang Raya. Jurnal Ilmu-ilmu Peternakan 27(3):81-87

Ekowati, T.,D, Sumarjono, H.Setyawan, E.Prasetyo.2014. Buku Ajar Usaha Tani.UPT Universitas Padjajaran Press. Semarang.

Karmila.2013. Faktor-Faktor Yang Menentukan Pengambilan Keputusan Peternak Dalam Memulai Usaha Peternakan Ayam Ras Petelur di Kecamatan Bissappu Kabupaten Bantaeng. Skripsi. Jurusan Sosial Ekonomi Peternakan. Fakutas Peternakan Universitas Hasanuddin. Makasar. 
Murti,A.T, Budi.H, Zaenal.F. 2015. Elastisitas Produksi Usaha Peternakan Broiler Pola Kemitraan di Kabupaten Blitar. J-PAL, Vol.6,No.2, 2015

Murti, A.T dan Santoso, E.P. 2017. Faktor-Faktor Yang Mempengaruhi Produksi Usaha Peternakan Broiler Pola Kemitraan di Kabupaten Blitar. Jurnal OPTIMA Vol.1No.1.

Nuryati Yati dan Nur Yudha Hadian.2012. Variabilitas Harga Telur Ayam Ras di Indonesia. Buletin Ilmiah Litbang Perdagangan Vol.6 No.2 Desember 2012

Saputra, A.A.2017. Analisis Faktor-Faktor Yang Mempengaruhi Permintaan Telur Ayam Ras di Kecamatan Semarang Tengah. E-Journal. Program Studi S1 Agribisnis Fakultas Peternakan dan Pertanian.Universitas Diponegoro.Semarang.

Siregar, R.I. 2003. Pengaruh Perubahan Waktu Pemberian Ransum dengan Berbagai Level Protein terhadap Performance Produksi Ras Petelur.Skripsi. Fakultas Peternakan.IPB.Bogor

Sarosa, P.2003. Kiat Praktis Membuka Usaha. Elex Media Komputindo.Jakarta.

Winoto, W.2012. Persiapan Memulai Usaha Agar Sukses. Http:www/wahyuwinoto.co/2012/persiapan-memulai-usaha-agar-sukses.com. Diakses Tgl. 20 Nopember 2017. 